\title{
Metal-Conductive Polymer Core-Shell Nanowires: Electroless Reduction of Pd and Cu on Polypyrrole/DNA Templates Bearing 2-2'-Bipyridyl Groups
}

\section{Mahdi Almaky"1, Reda Hassanien ${ }^{2}$, William Clegg ${ }^{3}$, Ross Harrington ${ }^{4}$, Andrew Houlton ${ }^{5}$ and Benjamin Horrocks ${ }^{6}$}

${ }^{*}$ Department of Chemistry, Faculty of Science, Sebha University, Sebha, Libya.

2 Department of Chemistry, Faculty of Science, New Valley University, El-Kharja, Egypt

${ }^{3,4}$ Chemistry, School of Natural and Environmental Sciences, Newcastle University, NE1 7RU, UK

5,6 Chemical Nanoscience Laboratory, School of Natural and Environmental Sciences, Newcastle University,

$$
\text { NE1 7RU, UK }
$$

\section{ABSTRACT}

A method for the preparation of conductive polymer nanowires bearing metal ion chelating 2,2'-bipyridyl groups is described. N-(3-pyrrol-1-yl-propyl)-2,2'-bipyridinium hexafluorophosphate (NP2PBH) was templated on $\lambda$-DNA in aqueous solution using $\mathrm{FeCl}_{3}$ as oxidant to initiate polymerization. The polyNP2PBH/DNA nanowires were then decorated with metals $\left(\mathrm{Cu}\right.$ or $\mathrm{Pd}$ ) by electroless deposition $\left[\mathrm{Cu}\left(\mathrm{NO}_{3}\right)_{2} /\right.$ ascorbate or $\mathrm{PdCl}_{4}{ }^{2-}$ $\left./ \mathrm{NaBH}_{4}\right]$. UV-vis absorption spectra of the hybrid materials show the absorption peak due to the plasmon resonance of $\mathrm{Cu}$ at about $550 \mathrm{~nm}$ and a broad continuous band consistent with metallic Pd in the range 300-700 $\mathrm{nm}$. The morphology, size and electrical properties of the hybrid nanostructures have been characterized using scanning probe techniques (atomic force microscopy (AFM), scanning conductance microscopy (SCM) and conductive atomic force microscopy (cAFM)). The polyNP2PBH/DNA nanowires show a continuous, smooth and uniform appearance (mean diameter $5.0 \mathrm{~nm}$ ). Cu deposits on polyNP2PBH/DNA nanowires by a nucleation and growth process that leads eventually to smooth, conductive $\mathrm{Cu}$ nanowires. In contrast, $\mathrm{Pd}$ deposits in a non-uniform manner on polyNP2PBH/DNA and has inconsistent electrical conductivity. The electrical conductivity of single $\mathrm{Cu} /$ polyNP2PBH/DNA nanowires was estimated to be $1.6 \pm 0.27 \mathrm{~S} \mathrm{~cm}^{-1}$ which we suggest is limited by electron transfer between $\mathrm{Cu}$ grains.

Keywords : Copper, Palladium, DNA, Nanowires, Poly(N-substituted) Pyrrole, Conductivity, Hybrid Nanostructures

\section{INTRODUCTION}

The distinctive aspects of DNA (chemical robustness, controlled length and well-defined rules for selfassembly) offer unique advantages for the preparation of nanoscale materials [1-5]. However, it is well known that DNA itself cannot be used as a "molecular wire" over micrometre length scales, because it is insulating on this length scale [6]. Nevertheless DNA is an effective template for the assembly of conductive nanowires from metals [7-10], semiconductors [11-13] and conjugated organic polymers [14-16]. There are also examples of templating on complex DNA structures, including origami [17-19].

$\mathrm{Cu}$ and $\mathrm{Pd}$ are important metallic nanowires which have attracted a great deal of research interest because of their electronic and chemical properties. $\mathrm{Cu}$ is the 
metal of choice for interconnects in integrated circuit technologies, due to its low relative cost and high electrical conductance $\left(6.0 \times 10^{5} \mathrm{~S} \mathrm{~cm}^{-1}\right.$ at $\left.293 \mathrm{~K}\right)$ [20]. There has therefore been strong interest in the fabrication of $\mathrm{Cu}$ nanowires [2]. The metallization of DNA with $\mathrm{Cu}$ as a route to preparing $1 \mathrm{D} \mathrm{Cu}$ nanostructures was reported by Woolley et al. [7]. Watson et al. [21] explored a process similar to that of Woolley; despite evidence for the metallic composition $\mathrm{Cu}(0)$ of these $\mathrm{Cu}$-DNA nanostructures, no evidence of electrical conductivity was observed. This was attributed to the "beads-on-a-string" morphology of the resulting $\mathrm{Cu}$ nanostructure. Electrically conducting $\mathrm{Cu} / \mathrm{DNA}$ nanostructures were subsequently prepared using multiple seeding steps [22]. Another synthetic approach for the preparation of conductive $\mathrm{Cu} / \mathrm{DNA}$ nanowires used DNA templating in bulk solution at low concentration [23]. More recently, we polymerized an N-propylpyridine derivative of pyrrole N-(3-pyrrol-1-yl-propyl)-4,4'bipyridinium hexafluorophosphate (polyNPPBH) on DNA templates and showed that upon metallization with $\mathrm{Cu}, \mathrm{Cu} /$ polyNPPBH/DNA nanowires are more electrically conductive than polyNPPBH/DNA nanowires [24]. research and write a research paper on some aspects of software engineering. The paper may present original work, discuss a new technique, provide a survey and evaluation of recent work in a given area, or give comprehensive and taxonomic tutorial information. The paper must emphasize concepts and the underlying principles and should provide authentic contribution to knowledge. If your paper does not represent original work, it should have educational value by presenting a fresh perspective or a synthesis of existing knowledge. The purpose of this document is to provide you with some guidelines. You are, however, encouraged to consult additional resources that assist you in writing a professional technical paper.
Pd nanomaterials have attracted attention because of their potential as electrocatalysts [25] and for applications in gas sensing [26,27]. Pd can be assembled on DNA via the chemical or photoinduced reduction of DNA-complexed metal ions [28-30]. Pd nanowires with small grain sizes $(<2 \mathrm{~nm})$ have been formed by the chemical reduction of $\mathrm{PdCl}_{4}{ }^{2-}$ in the presence of $\lambda$-DNA [27]. We have also previously reported that hybrid $\mathrm{Pd}$ on polyimidazole nanowires (Pd/PIm/DNA) can be fabricated by an electroless chemical route using PIm/DNA nanowires as templates [31].

Poly(pyrrole) is useful for DNA-templated nanowire synthesis because it can be polymerized in aqueous media, it interacts strongly with DNA [16], and it is possible to functionalize the polymer by derivatization of the monomer at the $\mathrm{N}$ atom [32]. The preparation of metal-binding derivatives allows the formation of hybrid metal/conductive polymer/DNA nanowires. In the present work, N-(3-pyrrol-1-yl-propyl)-2,2'-bipyridinium hexafluorophosphate (NP2PBH) was prepared via a regioselective chemical route (Supporting Information). 2,2'-Bipyridine was selected for two main reasons: first, it provides a chelating group to enhance the metal-binding capability for subsequent metal deposition; second, the pyridinium moieties enhance the cationic charge of the polyNP2PBH and favour adherence of the polymer to the anionic DNA template. In this work, the chemical structure, morphology and electrical properties of polyNP2PBH/DNA and $\mathrm{Cu}$ or Pd/polyNP2PBH/DNA wires are compared using spectroscopic and probe microscopy techniques.

\section{METHODS AND MATERIAL}

\section{Materials}

Lambda DNA (Bacteriophage lambda, $\lambda$-DNA, $500 \mu \mathrm{g}$ $\mathrm{mL}^{-1}, 10 \mathrm{mM}$ tris-HCl, $1 \mathrm{mM}$ EDTA, $\mathrm{pH} \mathrm{8,} \mathrm{Cat} \mathrm{no.}$ N3011S) was purchased from New England Biolabs (UK) Ltd. Calf thymus DNA (CT-DNA, highly 
polymerized, 6\% sodium) was purchased from SigmaAldrich. Ascorbic acid (99+\%) was purchased from Alfa Aesar. Pyrrole (99\%) was distilled under $\mathrm{N}_{2}$ prior to use. $\mathrm{MgCl}_{2} \cdot 6 \mathrm{H}_{2} \mathrm{O}$ (99.0\%), $\mathrm{FeCl}_{3}(>97 \%)$ and acetone $(\geq 99.8 \%)$, were purchased from SigmaAldrich (Dorset, UK). Acetonitrile (99.6\%) was purchased from Fisher Scientific (Loughborough, UK). Other general reagents were purchased from SigmaAldrich (Dorset, UK) and used as received. All solutions were prepared in water from a Barnstead Nanopure $^{\mathrm{TM}}$ purification train with a nominal resistivity of $18.2 \mathrm{M} \Omega \mathrm{cm}$. Si wafers were obtained from $\mathrm{PI}-\mathrm{KEM}$ as $\mathrm{n}-\mathrm{Si}(100) / \mathrm{SiO}_{2}$ for atomic force microscopy (AFM, cAFM) and scanned conductance microscopy (SCM) or p-Si (100) (for FTIR).

\section{Preparation methods}

The synthesis and characterization of the monomer, $\mathrm{N}$-(3-pyrrol-1-yl-propyl)-2,2'-bipyridinium

hexafluorophosphate (NP2PBH), was based on previously reported methods [33,34]. Details of our procedures are given in the Supporting Information.

\subsubsection{Preparation of bulk polyNP2PBH}

Bulk polyNP2PBH was prepared separately to polyNP2PBH/DNA as a control for the FTIR experiments. Aqueous $\mathrm{FeCl}_{3}$ solution $(1.0 \mathrm{mM}, 9 \mathrm{~mL})$ was added to an aqueous NP2PBH solution $(3.0 \mathrm{mM}$, $1 \mathrm{~mL}$ ) in a 3:1 mole ratio at room temperature. On stirring, the colour changed to dark brown and a precipitate formed after $4-5 \mathrm{~h}$. The polymer was filtered and washed with excess water. The polymer was then dried under vacuum at $40 \mathrm{C}$ for $5 \mathrm{~h}$. PolyNP2PBH was characterized using transmission FTIR spectroscopy (Supporting Information).

\subsubsection{Electrochemical polymerization of NP2PBH}

Electrochemical polymerization was carried out at room temperature in a conventional single compartment cell. The potentiostat was a model CH1760B (CH Instruments Inc., USA). The working electrode was a platinum disc of area $0.008 \mathrm{~cm}^{2}$. A tungsten wire and an aqueous $\mathrm{Ag} / \mathrm{AgCl}$ electrode (separated from the organic electrolyte by a ceramic frit) were used as a counter electrode and reference electrode. The solutions were degassed by dry nitrogen bubbling prior to the experiments. Electrooxidative polymerization was carried out in $\mathrm{CH}_{3} \mathrm{CN}$ containing $0.05 \mathrm{M}$ of monomer (NP2PBH) and $0.05 \mathrm{M}$ of $\mathrm{LiClO}_{4}$ (as electrolyte) by cycling between -1.8 and $+1.6 \mathrm{~V}$ at a scan rate of $100 \mathrm{mV} \mathrm{s}^{-1}$.

\subsubsection{Formation of $\lambda$-DNA-templated polyNP2PBH nanowires (poly NP2PBH / DNA)}

An aqueous $\mathrm{MgCl}_{2}$ solution ( $5 \mu \mathrm{L}, 0.5 \mathrm{mM}$ ) was added to an aqueous solution of $\lambda$-DNA (20 $\left.\mu \mathrm{L}, 500 \mathrm{ng} \mu \mathrm{L}^{-1}\right)$, followed by an aqueous NP2PBH solution $(5 \mu \mathrm{L}, 3$ $\mathrm{mM})$. A freshly prepared aqueous solution of $\mathrm{FeCl}_{3}(5$ $\mu \mathrm{L}, 3 \mathrm{mM}$ ) was then added to the NP2PBH/DNA solution and incubated at room temperature to form the DNA-templated nanowires denoted polyNP2PBH/DNA.

\subsubsection{Formation of calf thymus DNA-templated polyNP2PBH nanowires}

CT-DNA-templated polyNP2PBH nanowires were prepared for use in FTIR and UV-vis studies where larger quantities of material were required. An aqueous solution of CT-DNA (100 $\left.\mu \mathrm{L}, 0.5 \mathrm{ng} \mu \mathrm{L}^{-1}\right)$ was left to stand overnight to ensure the DNA was completely dissolved before use. Water $(125 \mu \mathrm{L})$ and aqueous NP2PBH solution (125 $\mu \mathrm{L}, 3 \mathrm{mM})$ were added. Next, freshly prepared aqueous $\mathrm{FeCl}_{3}(125 \mu \mathrm{L}, 3 \mathrm{mM})$ was added dropwise to the NP2PBH/DNA solution. The reaction was incubated for a period of at least $1 \mathrm{~h}$ at room temperature to form the CT-DNA-templated polyNP2PBH nanowires.

2.2.5 Metallization of polyNP2PBH/DNA hybrid nanowires

I) Templating $\mathrm{Cu}$ on polyNP2PBH/DNA hybrids nanowires ( $\mathrm{Cu} / \mathrm{polyNP2PBH/DNA)}$ 
A $\lambda$-DNA-templated polyNP2PBH solution (35 $\mu \mathrm{L}$, incubated at room temperature for $24 \mathrm{~h}$ ) was mixed with aqueous $\mathrm{Cu}\left(\mathrm{NO}_{3}\right)_{2}(5 \mu \mathrm{L}, 0.5 \mathrm{M})$ and allowed to stand for $10 \mathrm{~min}$. Ascorbic acid $(5 \mu \mathrm{L}, 1.0 \mathrm{M})$ was added and thoroughly mixed. The solution was allowed to react for at least $1 \mathrm{~h}$ at room temperature prior to analysis. Droplets of Cu-polyNP2PBH/DNA were deposited on $\mathrm{Si} / \mathrm{SiO}_{2}$ and oriented by the "molecular combing" technique [31]. In some experiments (UV-vis spectroscopy), larger volumes were required. In those cases, calf thymus DNA and appropriately scaled volumes of monomer, metal and oxidant were used (section 2.3.2).

\section{II) Templating Pd on polyNP2PBH/DNA hybrid nanowires (Pd/polyNP2PBH/DNA)}

PolyNP2PBH/DNA solution (35 $\mu \mathrm{L}$ ) was allowed to react for $24 \mathrm{~h}$ and then aqueous $\mathrm{K}_{2} \mathrm{PdCl}_{4}(5 \mu \mathrm{L}, 3 \mathrm{mM})$ was added and stirred for 10 minutes at room temperature. Next, aqueous $\mathrm{NaBH}_{4}(5 \mu \mathrm{L} 10 \mathrm{mM})$ was added and the solution was thoroughly mixed and allowed to react for at least $1 \mathrm{~h}$ at room temperature prior to analysis.

\subsection{Characterization}

\subsubsection{Fourier transform infrared spectroscopy}

Transmission FTIR spectra in the range $600-2000 \mathrm{~cm}^{-}$ 1 were recorded on a Bio-Rad Excalibur FTS-40 spectrometer (Varian Inc., Palo Alto, CA) equipped with a deuterated triglycine sulfate (DTGS) detector. 128 scans were co-added and averaged and the resolution was $4 \mathrm{~cm}^{-1}$. The samples were prepared by drop-casting aqueous solutions on clean p-type $\mathrm{Si}(100)$ substrates. Details of the cleaning procedure are given below in section 2.3.4. CT-DNA, polyNP2PBH/DNA, $\mathrm{Cu}$ or $\mathrm{Pd} /$ polyNP2PBH/DNA solutions $(8 \mu \mathrm{L})$ were deposited on a clean, hydrophilic p-type $\operatorname{Si}(100)$ substrate and left to dry for $1 \mathrm{~h}$ prior to analysis. A clean $\mathrm{p}-\mathrm{Si}(100)$ chip served as the background. Bulk polyNP2PBH samples were analysed using a $\mathrm{KBr}$ pellet technique.

\subsubsection{UV-vis absorption spectroscopy}

UV-vis absorbance spectra were recorded on a Varian-Cary 100 Bio spectrophotometer at room temperature. For UV-vis measurements, polyNP2PBH/DNA solution was prepared using calf thymus DNA (CT-DNA) (100 ng $\mu \mathrm{L}^{-1} ; 10 \mathrm{mM}$ tris- $\mathrm{HCl}$ $\mathrm{pH} 8,1 \mathrm{mM}$ EDTA). Typically, $0.6 \mathrm{~mL}$ of $3 \mathrm{mM}$ freshly prepared NP2PBH solution was added to $2 \mathrm{~mL}$ of CT-DNA solution in the presence of $0.5 \mathrm{mM} \mathrm{MgCl}_{2}$. Then, $0.6 \mathrm{~mL}$ of $\mathrm{FeCl}_{3}(1 \mathrm{mM})$ was added dropwise to the solution. The mixture was stirred and allowed to react at room temperature for $2 \mathrm{~h}$. A polyNP2PBH solution was prepared by the same process, in the absence of CT-DNA, as a control.

$\mathrm{Cu} /$ polyNP2PBH/DNA solution was prepared by adding $\mathrm{Cu}\left(\mathrm{NO}_{3}\right)_{2}(0.6 \mathrm{~mL}, 0.5 \mathrm{mM})$ to the previously prepared polymer-DNA solution. After allowing the reaction mixture to stand at room temperature for 10 min, $0.6 \mathrm{~mL}$ of $1 \mathrm{M}$ ascorbic acid solution was added to reduce the $\mathrm{Cu}^{2+}$ ions. The solution was thoroughly mixed and allowed to react for at least $1 \mathrm{~h}$ at room temperature prior to measurements.

$\mathrm{Pd} /$ polyNP2PBH/DNA solution was prepared by adding $0.6 \mathrm{~mL} \mathrm{PdCl} 4^{2-}(0.5 \mathrm{mM})$ to the polymer-DNA solution. After allowing the reaction mixture to stand at room temperature for $10 \mathrm{~min}, \mathrm{NaBH}_{4}(0.6 \mathrm{~mL}, 15$ $\mathrm{mM}$ ) solution was added to reduce the $\mathrm{Pd}^{2+}$ ions. The solution was thoroughly mixed and allowed to react for at least $1 \mathrm{~h}$ at room temperature prior to measurements.

\subsubsection{X-ray Photoelectron spectroscopy}

A Kratos Axis Ultra 165 photoelectron spectrometer equipped with a monochromic $\mathrm{Al} \quad \mathrm{K} \square \quad \mathrm{X}$-ray excitation source $(1486.7 \mathrm{eV})$ with an operating power of $150 \mathrm{~W}(15 \mathrm{kV}, 10 \mathrm{~mA})$ was used to collect photoemission spectra of $\mathrm{Cu} /$ polyNP2PBH/DNA and Pd/polyNP2PBH/DNA samples. The chamber pressure was $3.2 \times 10^{-9}$ Torr. The photoelectrons were 
filtered by the hemispherical analyzer and recorded by multichannel detectors. For the survey scan, the pass energy was $20 \mathrm{eV}$ and the step size was $0.3 \mathrm{eV}$. Some higher resolution spectra were recorded with a pass energy of $5 \mathrm{eV}$ and a step size of $0.1 \mathrm{eV}$. The binding energies obtained in the XPS analysis were calibrated using the lowest $\mathrm{C}_{1 \text { s }}$ component of DNA $(284.6 \mathrm{eV})$ as a reference. Spectral peaks were fitted using the WinSpec program developed by LISE laboratory, Universitaires Notre-Dame de la Paix, Namur, Belgium. $\mathrm{Cu}$ or $\mathrm{Pd} /$ polyNP2PBH/DNA samples were prepared for XPS by depositing $5 \mu \mathrm{L}$ of solution on a clean $\mathrm{Si}(100)$ substrate and then left to dry in air at room temperature in a laminar flow hood to minimize contamination (Model VLF 4B, Envair, Haslingden, Lancs, U.K.) before being inserted into the chamber.

\subsubsection{Preparation of substrates for atomic force microscopy}

Oxidized $\mathrm{Si} / \mathrm{SiO}_{2}$ wafers, (100) oriented, were used as substrates for AFM imaging, scanned conductance microscopy (SCM) and conductive atomic force microscopy (cAFM) . The $\mathrm{SiO}_{2}$ film thickness was about $220 \mathrm{~nm}$. The wafers were cut into chips $(1.0 \mathrm{~cm}$ $\mathrm{x} 1.0 \mathrm{~cm}$ ) with a diamond tip pen, then sequentially cleaned using a cotton bud soaked in acetone, propanol and finally water, and treated with "piranha" solution (4:1 $\mathrm{H}_{2} \mathrm{SO}_{4} / \mathrm{H}_{2} \mathrm{O}_{2}$ ) for 45 minutes (Caution! Piranha solution should be handled with extreme care; it is a strong oxidant and reacts violently with many organic materials). The chips were then rinsed with water and dried in an oven for 15 minutes at $50 \square \mathrm{C}$; this produces clean and hydrophilic surfaces.

Individual nanowires were aligned on $\mathrm{Si} / \mathrm{SiO}_{2}$ substrates by molecular combing [35]. First, the $\mathrm{SiO}_{2}$ was rendered hydrophobic by reacting the $\mathrm{Si} / \mathrm{SiO}_{2}$ with chlorotrimethylsilane (TMS) vapour (details below). Silanization facilitates combing and alignment of the templated DNA, because it reduces the adhesion of the nanowires to the substrate. Combing is achieved by dragging a droplet of nanowire solution across the surface using the tip of a pipette. Typically, 2-3 $\mu \mathrm{L}$ of $\mathrm{Cu}$ or $\mathrm{Pd} /$ polyNP2PBH/DNA solution was dropped onto the $\mathrm{Si} / \mathrm{SiO}_{2}$ surface and combed; the remaining solution was removed with a micropipette and/or wicked with filter paper. For cAFM experiments, $2 \mu \mathrm{L}$ of $\mathrm{Cu} /$ polyNP2PBH/DNA solution was drop-cast onto the substrate and the droplet was dragged to the edge of the chip and allowed to dry. This produces a dense mass of nanowires with a few aligned nanowires protruding from the main mass. Electrical contact to the mass of nanowires was made using In/Ga eutectic. Silanization of the Si substrates was performed by placing the substrate on top of a specimen bottle containing $100 \mu \mathrm{L}$ of TMS for 2-10 min to achieve a static contact angle for water between $60^{\circ}$ and $70^{\circ}$. Static contact angle measurements of the substrate before and after TMS-modification were carried out using a CAM100 system (KSV Instruments Ltd., Helsinki, Finland). Mean contact angle was determined by the included software (using a YoungLaplace method) via the mounted high resolution camera. The contact angle before TMS treatment was $<5^{\circ}$ using deionized water.

\subsubsection{Probe microscopy (AFM, SCM and cAFM)}

Atomic force microscopy (AFM) imaging was performed in air on a Dimension Nanoscope $\mathrm{V}$ (Bruker) using NanoProbe tips. All AFM images are height images unless otherwise indicated. Vibrational noise was reduced with an isolation system (TMC, Peabody, MA, USA).

For SCM and cAFM measurements, we used MESP probes (n type Si cantilevers, with a $\mathrm{Co} / \mathrm{Cr}$ coating, Bruker). These probes are 200-250 $\mu \mathrm{m}$ long, with a resonant frequency of about $79 \mathrm{kHz}$, a quality factor (Q) between 200 and 260, and a spring constant between 1 and $5 \mathrm{~N} \mathrm{~m}^{-1}$. For cAFM measurements, a 
constant bias was applied between the tip and the sample (the tip was grounded). Electrical contact was made by applying a drop of $\mathrm{In} / \mathrm{Ga}$ eutectic to one corner of the chip and to the metallic chuck. cAFM imaging was performed in contact mode, with an applied bias of $0.5 \mathrm{~V}$. The imaged area was about 1 $\mathrm{mm}$ away from the In/Ga contact. The closed loop system of the Dimension $\mathrm{V}$ instrument makes it possible to reproducibly position the tip at a point of interest identified in the image of the nanowires and to record $I-V$ measurements at that point. The resistance was estimated from the reciprocal of the slope of the $I$ - $V$ curve at zero bias.

\section{RESULTS AND DISCUSSION}

Several polymeric materials have been synthesized and characterized in this report. These are polyNP2PBH (which denotes poly(N-(3-pyrrol-1-ylpropyl)-2,2'-bipyridinium hexafluorophosphate), polyNP2PBH/DNA (which denotes polyNP2PBH nanowires prepared on a DNA template) and $\mathrm{Cu} /$ polyNP2PBH/DNA or Pd/polyNP2PBH/DNA (which denote metal $(\mathrm{Cu}$ or $\mathrm{Pd}$ ) shells deposited electrolessly on a polyNP2PBH/DNA core). The NP2PBH monomer was designed to contain: (a) a polymerizable group, pyrrole; (b) a flexible n-propyl chain linker; (c) a cationic pyridinium group to enhance binding to the anionic template and (d) a 2,2'-bipyridyl group as a metal ion-binding site (Fig. $1)$.

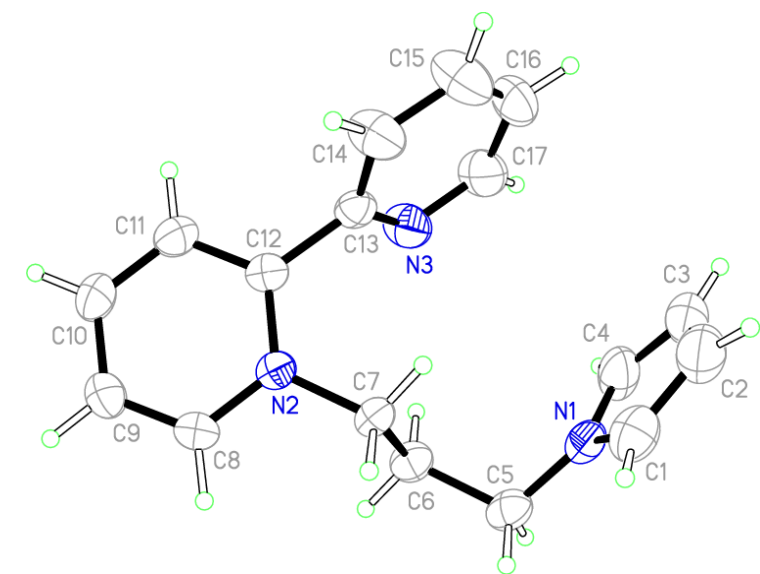

Figure 1: Structure of the cation of NP2PBH obtained from single-crystal X-ray diffraction (details in Supporting Information).

Electropolymerization of NP2PBH (Fig. 2) to form polyNP2PBH was studied using cyclic voltammetry (CV). PolyNP2PBH/DNA nanowires were chemically prepared by methods analogous to those used for simple poly(pyrrole)/DNA nanowires [16] and related derivatives [24]. FTIR spectroscopy showed that the polyNP2PBH/DNA nanowires consist of NP2PBH intimately associated with the DNA molecules. $\mathrm{Cu}^{0}$ and $\mathrm{Pd}^{0}$ were formed along the polyNP2PBH/DNA nanowires by electroless reduction of $\mathrm{Cu}^{2+}$ with ascorbate and of $\mathrm{PdCl}_{4}{ }^{2-}$ with $\mathrm{NaBH}_{4}$. FTIR, UV-vis and XPS spectroscopy were used to demonstrate the formation of poly(N-(3-pyrrol-1-yl-propyl)-2,2'bipyridinium and metal $(\mathrm{Cu}$ or $\mathrm{Pd})$ on the DNA templates. The morphology of the polyNP2PBH/DNA and $\mathrm{Cu}$ or $\mathrm{Pd} /$ polyNP2PBH/DNA nanowires was observed by atomic force microscopic (AFM) imaging. Finally, the electronic conductivities of polyNP2PBH/DNA and $\mathrm{Cu} /$ polyNP2PBH/DNA were estimated using scanned conductance (SCM) and conductive atomic force microscopy (cAFM).

\section{Electrochemical polymerization of NP2PBH}

$\mathrm{N}$-substitution of pyrrole tends to reduce the yield and the rate of electropolymerization of pyrroles $[32,36,37]$. Further, the electrode potential at which the substituted monomers are oxidised is usually 
higher than that of pyrrole itself $[37,38]$. Cyclic voltammetry at a $\mathrm{Pt}$ electrode in $50 \mathrm{mM}$ $\mathrm{LiClO}_{4} / \mathrm{CH}_{3} \mathrm{CN}$ electrolyte was used to study the electropolymerization of NP2PBH (Fig. 2a). The potential was scanned between -1.8 and $+1.6 \mathrm{~V}$ vs. an aqueous $\mathrm{Ag} / \mathrm{AgCl}$ reference electrode separated from the cell by a frit. As observed for the related pyrrole derivative, $\mathrm{PPBH}$ [24], the cyclic voltammogram shows a chemically-irreversible oxidation peak for the pyrrole group at about $+1.4 \mathrm{~V}$. The peak current decreased with repeated scans (down arrow) owing to consumption of monomer near the electrode surface and coating of the electrode surface with a polymer film. Simultaneously, peaks at potentials $<-0.5 \mathrm{~V}$ were observed that increased with repeated scans (up arrows). These must therefore be associated with other functionalities in the growing polymer film.

A single cycle of the voltammogram (Fig. $2 b$ ) shows clearly the oxidation/reduction peaks of the polyNP2PBH film. The voltammetry is very similar to the related 4,4'-bipyridiine species [24] and the peaks may be assigned similarly. Peaks 2 correspond to the reduction and re-oxidation processes of the quaternized nitrogens (N2 in the inset to Fig. 2b) of the alkylated pyridinium groups. Peaks 3 correspond to the localized redox processes of pyridine units that have not been quaternized and are available to bind metal ions (N3). Peaks 2 are substantially positive of peaks 3 , because of the positive charge on N2. The peaks labelled 1 are attributed to bipyridine groups (N1) that have reacted with the pyrrole units to produce quaterized nitrogens in a similar manner to that previously reported $[24,39]$. As noted in the case of polyNPPBH [24], this effect results in a lower conductivity of the polymer compared to poly(pyrrole). However this is an advantage in the case where conduction via the metallization rather than the polymer is desirable.
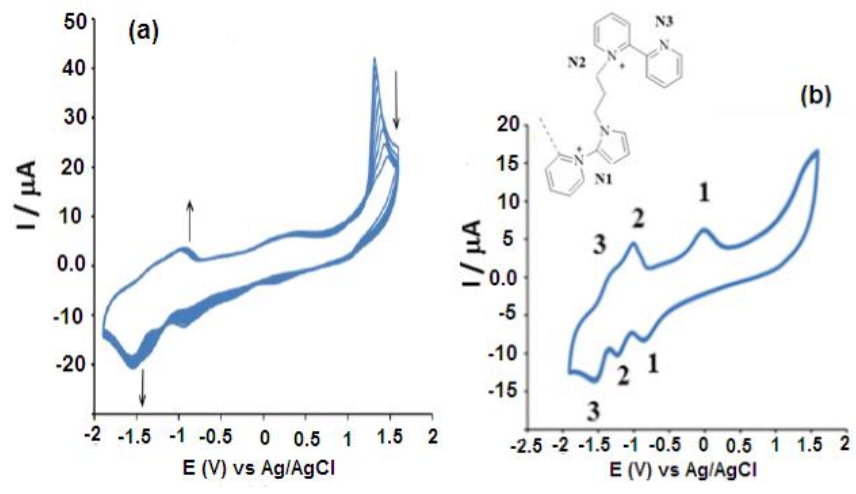

Figure 2: (a) Consecutive cyclic voltammograms for a platinum electrode in a solution containing $0.05 \mathrm{M}$ of $\mathrm{NP} 2 \mathrm{PBH}$ and $50 \mathrm{mM} \mathrm{LiClO}_{4} / \mathrm{CH}_{3} \mathrm{CN}$ as electrolyte. The arrows indicate change of current with cycle number. (b) A single cyclic voltammogram of the polyNP2PBH film that displays the peaks clearly. In both (a) and (b) the scan rate was $100 \mathrm{mV} \mathrm{s}^{-1}$ and the reference electrode was an aqueous $\mathrm{Ag} / \mathrm{AgCl}$ electrode separated from the $\mathrm{CH}_{3} \mathrm{CN}$ by a frit. 1, 2 and 3 refer to redox processes discussed in the text.

\section{DNA-templated nanowires (polyNP2PBH/DNA and M/polyNP2PBH/DNA)}

PolyNP2PBH/DNA nanowires were prepared by DNA-templating of polyNP2PBH through electroless chemical oxidation of NP2PBH with $\mathrm{FeCl}_{3}$ in an aqueous solution (Scheme 1).

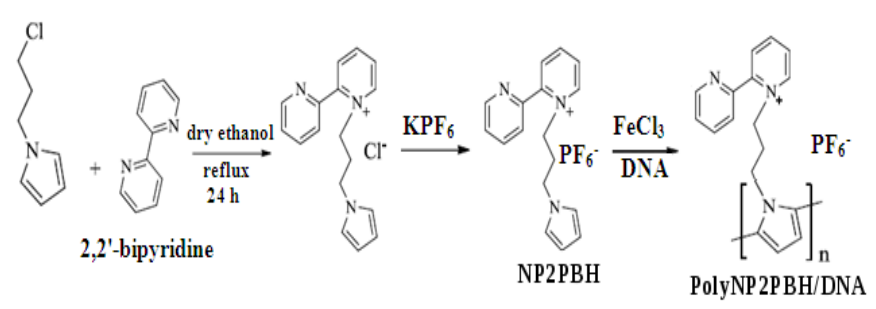

Scheme 1: Chemical polymerization of NP2PBH in an aqueous solution using $\mathrm{FeCl}_{3}$ as oxidant in the presence of DNA molecules.

\section{Infrared spectroscopy}

FTIR spectra were used to characterize the interaction of polyNP2PBH with calf-thymus (CT) DNA. The infrared spectral features related to this discussion are presented in Fig. 3 and a comparison of 
the NP2PBH and polyNP2PBH spectra are given in Supporting information. Overall, the most important observation is that the spectra are distinct in detail and the samples are therefore not simple mixtures of DNA, metal NPs and polymer.

The CT-DNA spectrum (Fig. 3a) shows the characteristic vibration modes of bare CT-DNA. The relevant bands and their assignments are tabulated in Table S3.2 in the Supporting Information. The FTIR spectra of the polyNP2PBH/DNA (Fig. 3b) and $\mathrm{Cu} /$ polyNP2PBH/DNA (Fig. 3c) samples show the same general features, but with some shifts compared with the spectrum of bare CT-DNA. Changes in band positions and intensities are apparent for the nucleobase vibrations in the $1400-1800 \mathrm{~cm}^{-1}$ region of the spectra. Additionally, the CT-DNA spectrum shows a broad feature at $1096 \mathrm{~cm}^{-1}$ from $-\mathrm{PO}_{2}^{-}$ symmetric stretches; this is shifted to lower wavenumbers at $1092 \mathrm{~cm}^{-1}$ for polyNP2PBH/DNA and further shifted to $1049 \mathrm{~cm}^{-1}$ in $\mathrm{Cu}-$ polyNP2PBH/DNA respectively. An intense infrared band at 835 and $837 \mathrm{~cm}^{-1}$ for polyNP2PBH/DNA and $\mathrm{Cu} /$ polyNP2PBH/DNA samples is characteristic of the $\mathrm{PF}_{6}{ }^{-}$anion [40] incorporated in the doped polymer to maintain electroneutrality. It is noteworthy that this counteranion is retained in the templated polymer and not displaced either by $\mathrm{Cl}^{-}$from the oxidant or the phosphate of the DNA.

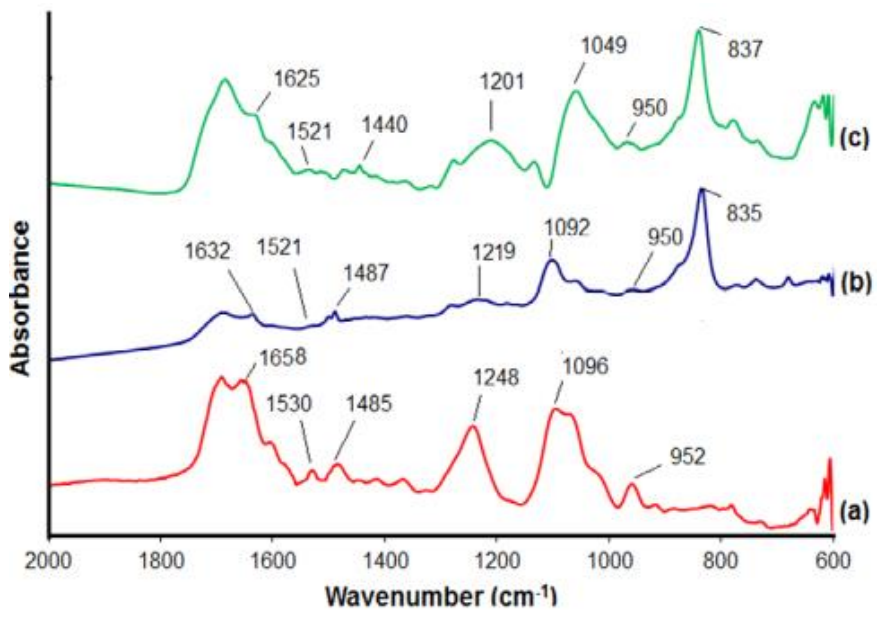

Figure 3: Transmission FTIR spectra of (a) CT-DNA (red), (b) polyNP2PBH/DNA (blue) and (c) $\mathrm{Cu} /$ polyNP2PBH/DNA (green); in the $2000-600 \mathrm{~cm}^{-1}$ region. 128 scans were co-added and averaged and the resolution was $4 \mathrm{~cm}^{-1}$. The spectra are offset on the $\mathrm{y}^{-}$ axis for clarity.

\section{UV-vis absorption spectroscopy}

The UV-vis absorption spectra of CT-DNA, NP2PBH, polyNP2PBH,polyNP2PBH/DNA, Cu /polyNP2PBH/ DNA and $\mathrm{Pd} /$ polyNP2PBH/DNA recorded at room temperature in aqueous solutions are shown in Fig. 4. Ascorbic acid and $\mathrm{NaBH}_{4}$ were chosen as the reducing agents following previous work [7, 27]. CT-DNA shows the expected absorption peak at $260 \mathrm{~nm}$ and no detectable absorption at wavelengths longer than 300 nm (black curve, Fig. 4a). The UV-vis absorption spectrum of NP2PBH (red curve, Fig. 4a) shows a strong absorption band around $290 \mathrm{~nm}$ and no detectable absorption above about $320 \mathrm{~nm}$. PolyNP2PBH (orange curve, Fig. 4a) also displays a strong absorption peak at $285 \mathrm{~nm}$. However, shoulders (assigned to $\pi-\pi^{*}$ transitions in the polymer backbone) were observed in the range $360-380 \mathrm{~nm}$ in the polyNP2PBH and polyNP2PBH/DNA spectra. Weak features near $480 \mathrm{~nm}$ are also observed (Supporting Information, Fig S4.1a). These are characteristic of the doped polymer and originate from transitions involving polaronic states.
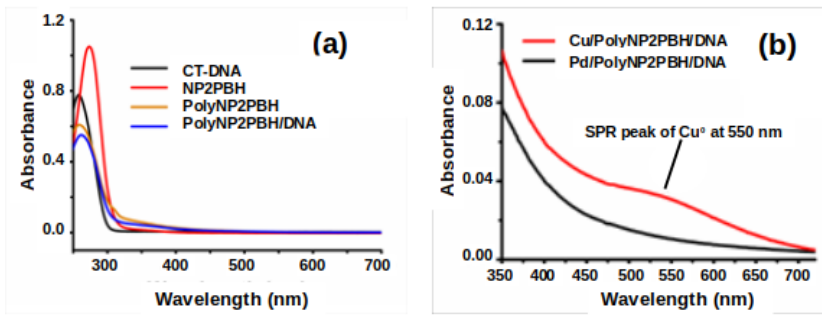

Figure 4: The UV-vis absorption spectra of the $\mathrm{Cu}-$ polyNP2PBH/DNA\& Pd-polyNP2PBH/DNA nanowires at different stages of the synthesis process were recorded at room temperature. (a) UV-vis absorption spectra of CT-DNA (black), NP2PBH (red), 
polyNP2PBH (orange) and polyNP2PBH/DNA (blue). NP2PBH-DNA solution treated with $\mathrm{Cu}\left(\mathrm{NO}_{3}\right)_{2}$ and $\mathrm{PdCl}_{4}{ }^{2-}$, then reduced with ascorbic acid and $\mathrm{NaBH}_{4}$ respectively. The spectra are offset on the $y$-axis for clarity. (b) The UV-vis absorption spectra of the $\mathrm{Cu}-$ polyNP2PBH/DNA \& Pd-polyNP2PBH/DNA; the absorption band at $550 \mathrm{~nm}$ corresponds to the peak of metallic $\mathrm{Cu}$ wires and the broad absorption in the range $300-700 \mathrm{~nm}$ corresponds to the peak of metallic Pd wires.

The spectrum of the $\mathrm{Cu}^{2+}$-polyNP2PBH/DNA complex prior to reduction (Fig. S4.1 Supporting Information) shows a broad absorption band for the $\mathrm{d}-\mathrm{d}$ transition of $\mathrm{Cu}^{2+}$ in the range 700-900 $\mathrm{nm}$ which disappeared upon addition of ascorbic acid and a distinctive knee at $550 \mathrm{~nm}$ was observed (red curve, Fig. 4b). The $550 \mathrm{~nm}$ band is consistent with the surface plasmon resonance of $\mathrm{Cu}$ nanostructures and provides evidence for the chemical reduction of $\mathrm{Cu}^{2+}$ to $\mathrm{Cu}^{0}$ in $\mathrm{Cu} /$ polyNP2PBH/DNA [41]. The UV-vis spectrum of $\mathrm{Pd} /$ polyNP2PBH/DNA solution (black curve, Fig. 4b) displays a broad absorption tail in the range $\quad 300-700 \mathrm{~nm}$. A comparison of polyNP2PBH/DNA and Pd/polyNP2PBH/DNA spectra (Fig. S4.1b, Supporting Information) shows an increase in absorption in this region after $\mathrm{Pd}$ metallization. This is consistent with the spectrum of metallic Pd nanowires $[27,29,42]$ and suggests the $\mathrm{Pd}$ metallization of polyNP2PBH/DNA nanowires. More direct evidence of $\mathrm{Pd}^{0}$ was supplied by photoelectron spectroscopy.

\section{$\mathrm{X}$-ray photoelectron spectroscopy}

A chemical analysis of $\mathrm{Cu}$ and $\mathrm{Pd} /$ polyNP2PBH/DNA was carried out using XPS. The survey spectrum for $\mathrm{Cu} /$ polyNP2PBH/DNA is shown in the Supporting Information; the elements detected were C, N, F O, P, and $\mathrm{Cu}$. A band in the $\mathrm{P} 2 \mathrm{p}$ spectrum at a binding energy of $132.1 \mathrm{eV}$ corresponds to the phosphate group and indicates the presence of DNA molecules in the nanowires. The $\mathrm{Fe}$ spectrum reveals the absence of either $\mathrm{Cl}^{-}$or Fe in the polyNP2PBH/DNA samples after washing. This confirms that $\mathrm{FeCl}_{3}$ is not strongly bound to the polymer. $\mathrm{F}$ was observed corresponding to the $\mathrm{PF}_{6}$ anion detected by FTIR above. The main features observed in the $\mathrm{C} 1 \mathrm{~s}$ spectrum for Cu-polyNP2PBH/DNA were at 284.6, 286.2, 288.1, and $289.0 \mathrm{eV}$ (Supporting Information).

Fig. 5a shows the $\mathrm{Cu} 2 \mathrm{p}$ region of the XPS spectra of $\mathrm{Cu} /$ polyNP2PBH/DNA which features the $\mathrm{Cu} 2 \mathrm{p}_{3 / 2}$ and 2p $\mathrm{p}_{1 / 2}$ binding energies located at 932.3 and 952.1 $\mathrm{eV}$ that fall within the expected range for metallic $\mathrm{Cu}^{0}$ $[43,44]$. The difference in binding energy of these two peaks is $19.8 \mathrm{eV}$, which is in agreement with the established values for the $2 \mathrm{p}^{1 / 2}-2 \mathrm{p}^{3 / 2}$ splitting in metallic $\mathrm{Cu}^{0}$ nanowires [45]. Additional components at 933.6 and $953.6 \mathrm{eV}$ are assigned to $\mathrm{Cu}$ (II) species and this is confirmed by the presence of the shake-up satellite at $944 \mathrm{eV}$. This can also be attributed to $\mathrm{Cu}$ (II) species, originating from the $\mathrm{Cu}\left(\mathrm{NO}_{3}\right)_{2}$ starting material.
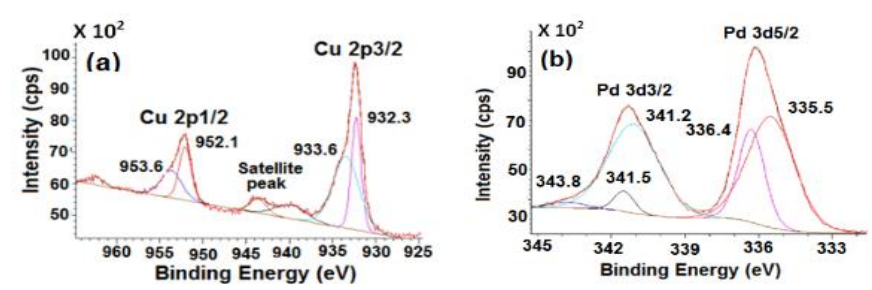

Figure 5: XPS of the as-prepared nanowires. (a) The XPS core level spectrum of the $\mathrm{Cu} 2 \mathrm{p}$ region for $\mathrm{Cu} /$ polyNP2PBH/DNA. $\mathrm{Cu}_{2 p 3 / 2}$ and $\mathrm{Cu}_{2 p 1 / 2}$ peaks appear at 932.3 and $952.1 \mathrm{eV}$ respectively, which can be attributed to $\mathrm{Cu}^{0}$. Two additional components are detected at 933.6 and 953.6 for $\mathrm{Cu}_{2 \mathrm{p} 3 / 2}$ and $\mathrm{Cu}_{2 \mathrm{p} 1 / 2}$ which can be attributed to $\mathrm{Cu}(\mathrm{II})$. A satellite feature is also observed around $944 \mathrm{eV}$. (b) The XPS core-level spectrum of the $\mathrm{Pd}_{3 \mathrm{~d}}$ region for $\mathrm{Pd} /$ polyNP2PBH/DNA. Two peaks detected at $335.5 \mathrm{eV}\left(\mathrm{Pd}_{3 \mathrm{~d} 5 / 2}\right)$ and $341.2 \mathrm{eV}$ $\left(\mathrm{Pd} 3 \mathrm{~d}_{3 / 2}\right)$ are attributed to $\mathrm{Pd}^{0}$ species. The other two components at $336.4 \mathrm{eV}\left(\mathrm{Pd} 3 \mathrm{~d}_{5} / 2\right)$ and $341.5 \mathrm{eV}(\mathrm{Pd}$ $3 \mathrm{~d}_{3 / 2}$ ) correspond to higher energies than the two 
former peaks, which implies a higher oxidation state such as $\mathrm{Pd}(\mathrm{II})$. The binding energies are reported after calibration of the energy scale so that the lowest DNA $\mathrm{C}_{1 \mathrm{~s}}$ binding energy is $284.6 \mathrm{eV}$.

The XPS $\mathrm{Pd}_{3 \mathrm{~d}}$ spectrum acquired for a $\mathrm{Pd}$ polyNP2PBH/DNA sample is depicted in Fig. 5b. The Pd 3d spectra are characterized by the spin-orbit

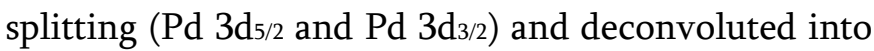
two major components. The low binding energy component at $335.5 \mathrm{eV}\left(\mathrm{Pd} 3 \mathrm{~d}_{5 / 2}\right)$ and $341.2 \mathrm{eV}(\mathrm{Pd}$ $\left.3 \mathrm{~d}_{3 / 2}\right)$ is assigned to $\mathrm{Pd}^{0}$ species and confirms the presence of $\mathrm{Pd}$ metal. The other significant peaks located at slightly higher energies (336.4 and $341.5 \mathrm{eV}$ ) are assigned to $\mathrm{Pd}^{\text {(II) }}$. The other small peak at $343.8 \mathrm{eV}$ is attributed to $\mathrm{Pd}$ plasmons. In summary, these results indicate a partial reduction of $\mathrm{Pd}^{(\mathrm{ii})}$ to $\mathrm{Pd}^{0}$ by the treatment with $\mathrm{NaBH}_{4}$ as a reducing agent. This is consistent with previous findings [27].

\section{Atomic force microscopy of polyNP2PBH/DNA}

The morphology of the polyNP2PBH/DNA and $\mathrm{Cu}$ or $\mathrm{Pd} /$ polyNP2PBH/DNA nanowires was investigated using tapping mode AFM. Samples were deposited and combed on $\mathrm{Si} / \mathrm{SiO}_{2}$ substrates that had been treated with trimethylchlorosilane. Images of polyNP2PBH/DNA nanowires were taken after $2 \mathrm{~h}$ and after $24 \mathrm{~h}$. At the shorter reaction times, $2 \mathrm{~h}$, the AFM image in Fig. 6a reveals a mixture of bare DNA molecules (red arrows) and polyNP2PBH/DNA (blue arrows). The measured thickness (AFM height) of the bare DNA was in the range of 0.5 to $2.0 \mathrm{~nm}$. PolyNP2PBH/DNA nanowires are observed to have heights ranging from 4 to $15 \mathrm{~nm}$; they appear straight, with continuous polymer coating and have lengths that are greater than the maximum scan range of 10 $\square \mathrm{m}$ as expected from the $16.7 \square \mathrm{m}$ length of $\square$-DNA. Individual polyNP2PBH/DNA nanowires are typically smooth and regular in diameter, but they occasionally show branches, e.g., on the left of Fig. 6a, which suggests that they comprise multiple strands wound together. Indeed, Fig. 6b shows an AFM image of a polyNP2PBH/DNA "nanorope" formed $24 \mathrm{~h}$ after preparation with a diameter of $30 \mathrm{~nm}$. Near the top of the image the rope structure splits into two nanowires with diameters of 10 and $20 \mathrm{~nm}$. The formation of rope-like structures is quite general for DNAtemplated polymer nanowires in which the charge on the DNA is compensated by the cationic conductive polymer [46]. Overall, the AFM observations of polyNP2PBH/DNA are consistent with our previous findings that conductive polymers produce regular and smooth nanowires when templated on $\lambda$-DNA by oxidative chemical polymerization [47].

Fig. 6c compares the height (diameter) distributions of 100 bare DNA molecules and 100 polyNP2PBH/DNA nanowires. The bare DNA samples show a bimodal distribution with a large peak in the $0-1$ and 1-2 $\mathrm{nm}$ bins due to single molecules and a much smaller peak in the 4-6 $\mathrm{nm}$ range due to bundles. However, the distribution for polyNP2PBH/DNA samples is distinctly different; not only does it extend to larger diameter structures, but it is monomodal with a mean diameter of $\sim 5 \mathrm{~nm}$. Some bare DNA is clearly still present, but much thicker structures are evident due to templating of the polymer on the DNA. The AFM data for metallized polyNP2PBH/DNA is discussed below alongside the SCM data because the conductance provides additional information on the continuity of the structures. 

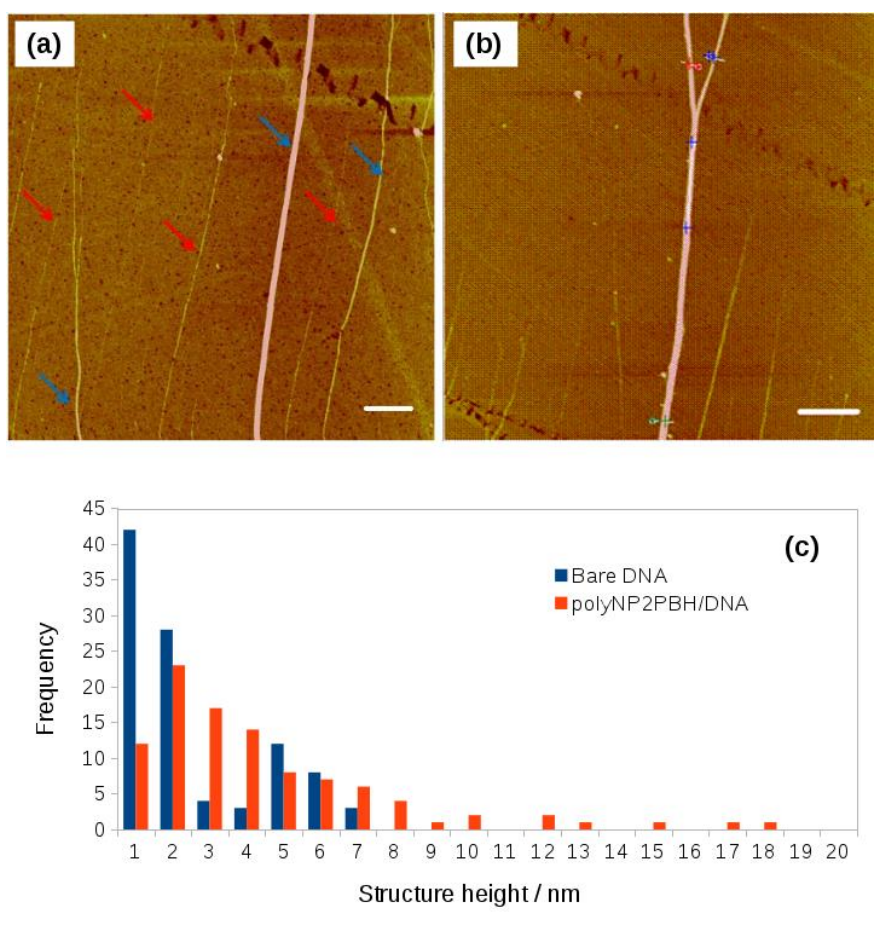

Figure 6: Tapping mode AFM images of polyNP2PBH/DNA, Cu-polyNP2PBH/DNA and PdpolyNP2PBH/DNA nanowires aligned on $\mathrm{Si} / \mathrm{SiO}_{2}$ substrates after different incubation times; (a) AFM height image of polyNP2PBH/DNA nanowires after 2 $\mathrm{h}$, the red arrows indicate the bare DNA molecules and blue arrows indicate the polyNP2PBH/DNA nanowires. Scale bar $=500 \mathrm{~nm}$, height scale $=20 \mathrm{~nm}$. (b) AFM height image of polyNP2PBH/DNA nanorope after $24 \mathrm{~h}$. Scale bar $=500 \mathrm{~nm}$, height scale $=20 \mathrm{~nm}$. (c) Tapping mode AFM height image of $\mathrm{Cu}-$ polyNP2PBH/DNA nanowires after $1 \mathrm{~h}$; Scale bar = 1 $\mu \mathrm{m}$, height scale $=20 \mathrm{~nm}$. (d) Tapping mode AFM height image of $\mathrm{Cu} /$ polyNP2PBH/DNA nanowires after $48 \mathrm{~h}$; scale bar $=200 \mathrm{~nm}$, height scale $=20 \mathrm{~nm}$. (e) Tapping mode AFM height image of $\mathrm{Pd}-$ polyNP2PBH/DNA; scale bar $=200 \mathrm{~nm}$, height scale = $20 \mathrm{~nm} .(48 \mathrm{~h})$. (f) Height distribution of $\sim 100 \lambda$-DNA molecules after templating with polyNP2PBH; the heights were determined from tapping mode AFM images $2 \mathrm{~h}$ after preparation. It is also apparent from inspection of the histogram that not all the DNA in the reaction is involved in templating. This is evident from the peak observed at $2.0 \mathrm{~nm}$, which mainly represents bare DNA that is present after the templating reaction.

\section{Electrical characterization of polyNP2PBH/DNA and $\mathrm{M} /$ polyNP2PBH/DNA using SCM and AFM characterization of M/polyNP2PBH/DNA}

Scanned conductance microscopy (SCM) is used to detect conductive objects on a dielectric film through their effect on the capacitance between the metallized tip and the underlying substrate [48-49]. The technique operates in lift mode in which the topography is determined in a first pass along a line. In the second pass, the tip is lifted a preset height (typically tens of $\mathrm{nm}$ ) above the topography and the phase of the tip motion with respect to the driving force is observed. Previous results have demonstrated that extended conducting structures show a negative (dark) phase shift with respect to the background under the usual AFM convention [48]. In contrast, insulating materials always show a positive (bright) phase shift no matter how high their polarisability. SCM is essentially the same experiment as electric force microscopy (EFM); however, phase shifts due to conductance effects show a parabolic dependence on the dc bias between tip and substrate. Such effects can then be distinguished from electric force effects due to surface charges, which have a linear dependence on the dc bias.

SCM was used for characterizing the electrical properties of both polyNP2PBH/DNA and $\mathrm{M} /$ polyNP2PBH/DNA nanowires; it allows a contactless, but qualitative assessment of the nanowire conductance and the AFM topography is obtained in the same experiment as the phase image. In this work, SCM phase images were recorded with the tip lifted $60 \mathrm{~nm}$ above the sample surface and a dc voltage in the range -10 to $+10 \mathrm{~V}$ was applied between the tip and the substrate. The SCM images are presented alongside the AFM topographic images acquired simultaneously in Figs. 7 and 8. 
Fig. 7a shows an SCM phase image of a polyNP2PBH/DNA nanowire recorded at a bias voltage of $+6 \mathrm{~V}$. As the tip crossed the nanowires, a negative-positive-negative (W-shaped) phase variation was observed (Fig. $7 \mathrm{~b}$ ). This is a known phenomenon in conducting polymer fibres $[49,50]$. Some bare DNA molecules are also present in this image, (red arrow), which are non-conductive as judged by their weak positive phase shift. The polyNP2PBH/DNA nanowire appears as a dark line running north/south through the centre of the SCM phase image (Fig. 7a); this corresponds to a negative phase shift as the tip crosses the nanowire and demonstrates the existence of a continuous charge conduction pathway in the wire. The phase shift was measured along a cross section of the nanowire with a diameter of $10 \mathrm{~nm}$ and at various applied bias voltages between -10 and $+10 \mathrm{~V}$. The expected parabolic dependence of phase shift on bias for voltages between -10 and $+10 \mathrm{~V}$ confirms that the origin of the phase shift is indeed the scanned conductance effect.

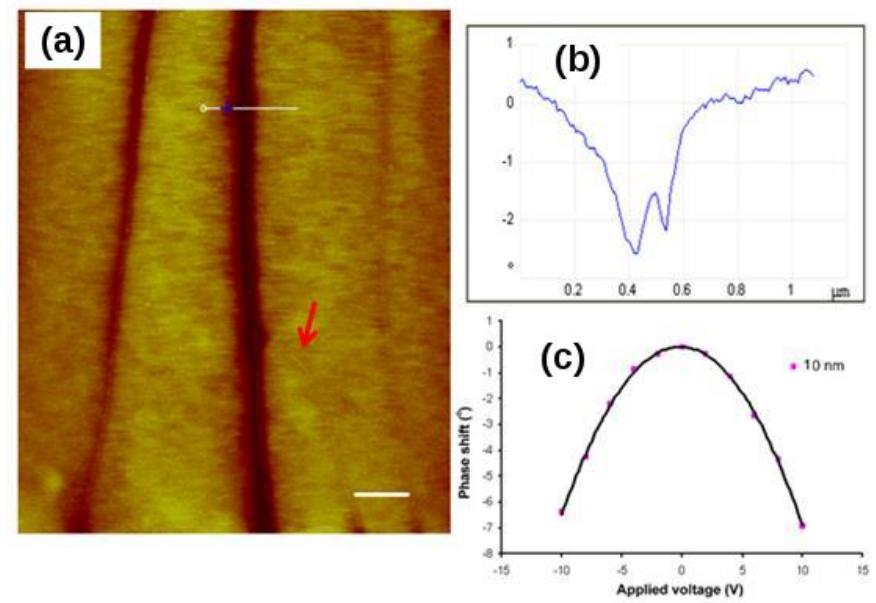

Figure 7: (a) SCM phase image of polyNP2PBH/DNA nanowires at a tip/sample bias of $+6 \mathrm{~V}$ and lift height of $60 \mathrm{~nm}$. The red arrow indicates a bare DNA molecule with positive phase shift. Scale bar $=500 \mathrm{~nm}$. (b) Profile of the phase across the polyNP2PBH/DNA nanowire of (a) along the white line in the top, centre of the image. (c) Bias voltage dependence of the maximum absolute phase shift in (b) and least squares fit of a parabolic function of the bias.

Fig. 8a shows a tapping mode AFM image of $\mathrm{Cu} /$ polyNP2PBH/DNA nanostructures $1 \mathrm{~h}$ after electroless $\mathrm{Cu}$ deposition. As well as an increase in the nanowire thickness, non-specific deposition of $\mathrm{Cu}^{0}$ particles with a large variation in height, $1.0-20 \mathrm{~nm}$, is observed across the substrate surface. Uneven coverage of the template is apparent with a great variation in structure height indicating the nonuniform deposition of $\mathrm{Cu}^{0}$ along the length of the polyNP2PBH/DNA templates. Regions of the template exhibit extensive $\mathrm{Cu}^{0}$ deposition, up to ca. 25 $\mathrm{nm}$ in height. Values as low as ca. $5 \mathrm{~nm}$ are also observed where less significant levels of metallization have taken place (Fig. 6c: A,B). It is not clear from the AFM images whether the deposition of $\mathrm{Cu}$ is continuous along the polyNP2PBH/DNA template or not, but this can be established from the SCM data.

Fig. $8 \mathrm{~b}$ shows the SCM phase image corresponding to Fig. 8a. There are two dark lines running approximately north/south on the left of the image in Fig. 8b; these correspond to thicker $\mathrm{Cu} /$ polyNP2PBH/DNA structures in the AFM image and are clearly conductive. However, where the structures have a "beads-on-a-string" appearance (blue rectangle), the phase shift is positive and indicates there is no continuous path for charge to flow outside the region underneath the tip. Bearing in mind the data for polyNP2PBH/DNA, it is likely that these regions correspond to $\mathrm{Cu}$ deposits on bare DNA molecules. This is consistent with previous reports of $\mathrm{Cu} / \mathrm{DNA}$ nanostructures [21]. 

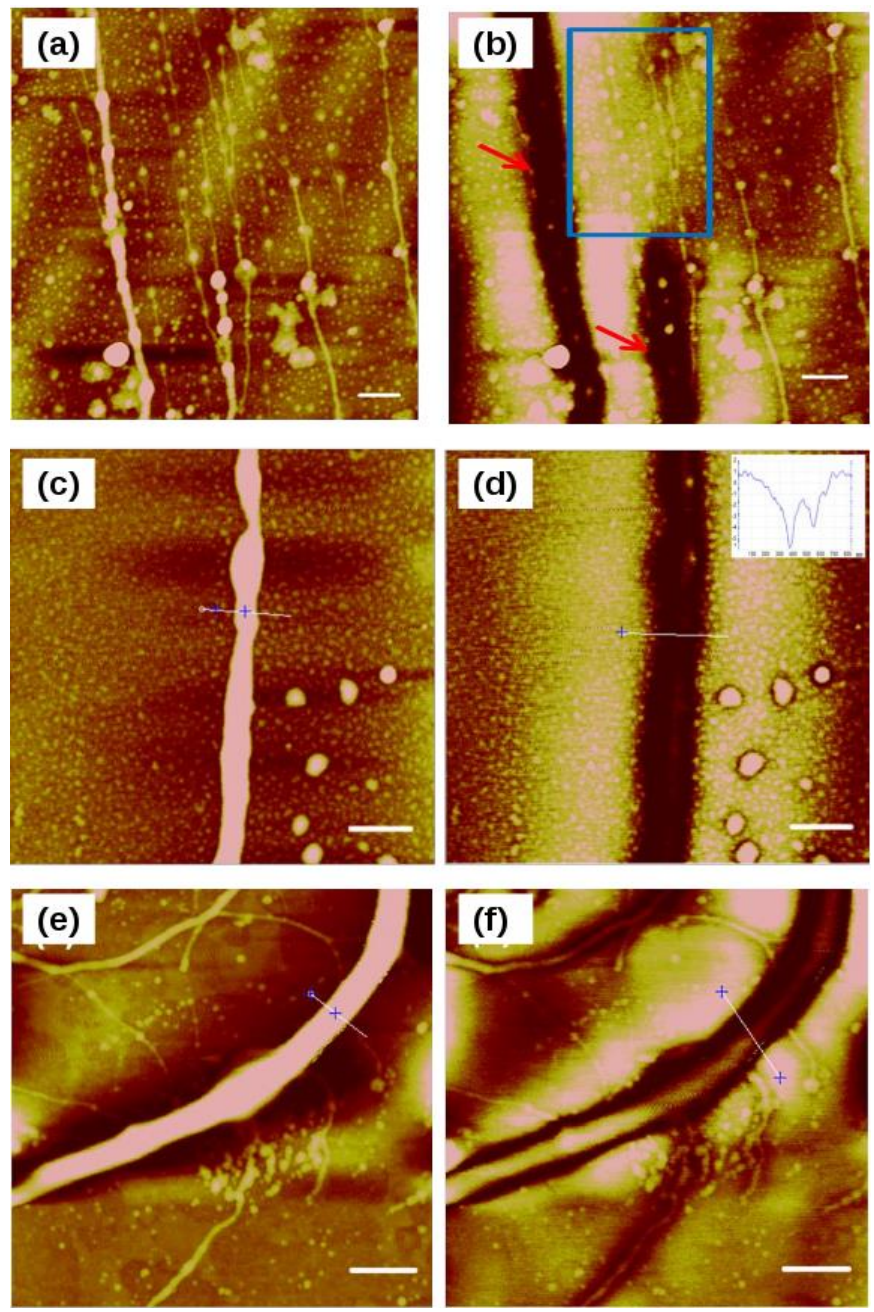

Figure 8: (a) Tapping mode AFM image of a $\mathrm{Cu} /$ polyNP2PBH/DNA nanowire $1 \mathrm{~h}$ after $\mathrm{Cu}$ deposition. Scale bar $=1 \mu \mathrm{m}$ and the height grayscale $=20 \mathrm{~nm}$. (b) The corresponding SCM phase image to (a) at a tip - sample bias of $+6 \mathrm{~V}$ and lift height of 60 nm. (c) Tapping mode AFM image of a $\mathrm{Cu} /$ polyPPBH/DNA nanowire $24 \mathrm{~h}$ after $\mathrm{Cu}$ deposition. The scale bar $=500 \mathrm{~nm}$ and the height grayscale $=20 \mathrm{~nm}$. (d) The corresponding SCM phase image to (c) at a tip - sample bias of $+6 \mathrm{~V}$ and lift height of $60 \mathrm{~nm}$. (e) AFM image of $\mathrm{Pd} /$ polyNP2PBH/DNA nanowires $24 \mathrm{~h}$ after $\mathrm{Pd}$ deposition. The scale bar $=300 \mathrm{~nm}$ and the height grayscale $=30 \mathrm{~nm}$. (f) The corresponding SCM phase image to (e) at a tip/sample bias of $+6 \mathrm{~V}$ and lift height of $60 \mathrm{~nm}$.
Fig. 8c shows a tapping mode AFM image of $\mathrm{Cu} /$ polyNP2PBH/DNA nanostructures $24 \mathrm{~h}$ after electroless $\mathrm{Cu}$ deposition. After longer periods of metallization we observe much thicker $\mathrm{Cu} /$ polyNP2PBH/DNA nanowires with a more uniform morphology, but some nanoparticles remain (additional images in Supporting Information). The corresponding SCM phase image (Fig. 8d), which has been taken at a tip/sample bias of $+6 \mathrm{~V}$ and lift height of $60 \mathrm{~nm}$, shows a large negative phase shift. The inset on Fig. 8d shows the corresponding profile of the phase shift along a cross-section of the nanowire. The expected parabolic dependence of phase shift on bias for voltages between -10 and $+10 \mathrm{~V}$ is also observed (Supporting Information). It is not, however, possible to conclude from the SCM data alone whether $\mathrm{Cu} /$ polyNP2PBH/DNA nanowires are more conductive than polyNP2PBH/DNA structures. In the next section, we present direct cAFM data to make quantitative measurements of the conductivity.

$\mathrm{Cu}^{0}$ deposition off the template is observed as small particles in the bottom right hand corner of Figs. 8c and $8 \mathrm{~d}$. These particles exhibit a positive phase shift in Fig. 8d, which is a consequence of the fact that they are not well connected to form a conduction pathway. Disconnected metal particles do not produce the same response as nanowires because the mobile charge cannot move outside the region underneath the oscillating tip and the response is similar to that produced by a structure which is merely polarisable and does not have charges that are mobile on the timescale of the tip oscillation frequency.

In general, the morphology of $\mathrm{Cu}$ templated on polyNP2PBH/DNA is noticeably different from that of $\mathrm{Cu} /$ polyNPPBH/DNA previously reported in which heavily branched structures are formed [24]. We attribute the morphology of the $\mathrm{Cu} /$ polyNP2PBH/DNA to a nucleation and growth 
mechanism for $\mathrm{Cu}^{0}$ deposition on the polyNP2PBH/DNA templates. Initial $\mathrm{Cu}^{0}$ nuclei act as seeds for further reduction of $\mathrm{Cu}^{2+}$ at their surface, resulting in the particles observed in Fig. 8a. We tentatively suggest that the difference is a result of the chelating nature of the NP2PBH ligand in the present work.

PolyNP2PBH/DNA nanostructures were also used as templates to direct $\mathrm{Pd}$ nanowire formation. The electroless deposition method reported here is similar to that has been used for the templating of Pd directly on DNA [27]. Fig. 8e shows Pd/polyNP2PBH/DNA nanostructures formed by the addition of $\mathrm{PdCl}_{4}{ }^{2-}$ to the polyNP2PBH/DNA suspension and reduction with $\mathrm{NaBH}_{4}$. This sample was imaged $48 \mathrm{~h}$ after addition of the reducing agent. The growth of $\mathrm{Pd}$ on the polyNP2PBH/DNA template is indicated by an increase in height to about $25 \mathrm{~nm}$ after metallization. However, these nanowires vary in size (up to $\sim 45 \mathrm{~nm}$ ) and are less regular and uniform compared to those before metallization. They also show extensively branched structures unlike $\mathrm{Cu} /$ polyNP2PBH/DNA (Fig. 8c).

Fig. $8 \mathrm{f}$ is the corresponding SCM phase image of the $\mathrm{Pd} /$ polyNP2PBH/DNA nanowire of Fig. 8e (applied bias $=+6 \mathrm{~V}$, lift height $60 \mathrm{~nm}$ ). As the tip crosses the nanowire a negative-positive-negative phase variation is observed. Upon varying the applied bias and measuring the phase shift at the most negative point along a cross section of the nanowire at a diameter of $25 \mathrm{~nm}$, the expected parabolic dependence of phase shift on bias for voltages between -10 and $+10 \mathrm{~V}$ was observed (Supporting Information). It is notable that the $\mathrm{Pd} /$ polyNP2PBH/DNA nanowire of Fig. 8f does not show a uniform phase shift along its length unlike the $\mathrm{Cu} /$ polyNP2PBH/DNA nanowire of Fig. 8c; this suggests that the growth of $\mathrm{Pd}$ on polyNP2PBH is less uniform than for $\mathrm{Cu}$. The XPS data shows evidence of $\mathrm{Pd}(\mathrm{II})$ species remaining and therefore the lack of uniformity in the Pd/polyNP2PBH/DNA SCM data is likely a result of incomplete reduction and hydrolysis of the $\mathrm{PdCl}_{4}{ }^{2-}$.

\section{Electrical properties of $\mathrm{Cu} /$ polyNP2PBH/DNA wires using cAFM}

In our cAFM experiments, networks of nanowires were deposited on a $\mathrm{Si} / \mathrm{SiO}_{2}$ substrate, with a single $\mathrm{In} / \mathrm{Ga}$ contact connecting the whole mass of nanowires to the external circuit. The second electrical contact was made by the metallized cAFM tip. The imaged area was about $1 \mathrm{~mm}$ away from the $\mathrm{In} / \mathrm{Ga}$ eutectic contact. When using individual nanowire in contact mode, the tip disturbs and pushes nanowire away during scanning. For this reason, it is preferable to use a network of nanowires instead of individual nanowires. Conductive AFM measurements of nanowires were made using the procedure previously described [50]. cAFM images of $\mathrm{Cu} /$ polyNP2PBH/DNA nanowires are presented in Fig. 9. The plot of the circuit resistance as a function of the relative distance, $d$, along the $\mathrm{Cu} /$ polyNP2PBH/DNA nanowire is shown in Fig. 10. The resistance increases with " $d$ " because the current must flow through a longer portion of the nanowire.

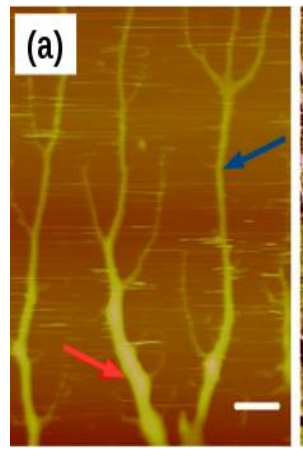

Figure $9:$ cAFM measurements of $\mathrm{Cu} /$ polyNP2PBH/DNA nanowires aligned on a $\mathrm{SiO}_{2} / \mathrm{Si}$ substrate (oxide thickness $=220 \mathrm{~nm}$ ). (a) Contact mode image (the greyscale corresponds to a height of $13 \mathrm{~nm}$ ); (b) deflection error image and (c) current image (the greyscale corresponds to a current of 100 
$\mathrm{nA}$ ). The tip-sample bias was $0.5 \mathrm{~V}$ and images (a)-(c) were acquired simultaneously. Scale bars $=1.5 \mu \mathrm{m}$.

cAFM images of $\mathrm{Cu} /$ polyNP2PBH/DNA were obtained by depositing a droplet of the nanowire solution on a clean $\mathrm{SiO}_{2} / \mathrm{Si}$ substrate. As the droplet dries, a large mass of nanowires is deposited, but, at the receding edge of the meniscus, some nanowires are aligned normal to the boundary. One electrical contact is made directly to the main mass using In/Ga eutectic and the second by the CAFM tip to one of the aligned nanowires visible in Fig. 9. The quality of the topographic image (Fig. 9a) is worse than the tapping mode images in Fig. 8, because cAFM is a contact mode technique. However, the nanowires are clearly visible in both the topographic and deflection error images. These images show ropes of nanowires with branches owing to the intertwining that happens during the deposition process. The diameter of the nanowires ranges from about $50 \mathrm{~nm}$ (red arrow, Fig. 9a) to about $15 \mathrm{~nm}$ (blue arrow, Fig. 9a). The current image (Fig. 9c) demonstrates clearly the continuity and conductivity of the nanowires and the absence of leakage currents through the substrate.

Fig. 10 shows the resistance data collected for a relatively uniform portion of the $\mathrm{Cu} /$ polyNP2PBH/DNA nanowires of height about 15 $\mathrm{nm}$. At each point, a current-voltage (I-V) curve was recorded and the resistance was determined from as the reciprocal of the slope of the I-V curve at zero bias. Using the closed loop positioning system, the tip was then moved further along the nanowire and the resistance measured at a series of points increasingly further away from the In/Ga contact. The I-V curves are sensitive to the contact resistance at the tip/nanowire junction and the process was therefore repeated at different deflection setpoints. Higher deflection setpoints correspond to higher tip/sample forces and lower tip/sample contact resistances. Linear regression of the data in Fig. 10 gives a resistance per unit length of $2.9 \pm 0.5 \mathrm{M} \square \square \mathrm{m}^{-1}$. Using the measured height $(15 \mathrm{~nm})$ and width $(230 \mathrm{~nm})$ of the features, we estimate a conductivity of $1.6 \pm 0.27 \mathrm{~S}$ $\mathrm{cm}^{-1}$ for $\mathrm{Cu} /$ polyNP2PBH/DNA. This conductivity is much lower than that of bulk $\mathrm{Cu}\left(6.0 \times 10^{5} \mathrm{~S} \mathrm{~cm}^{-1}\right)$ [20], although it is greater than the $0.42 \pm 0.019 \mathrm{~S} \mathrm{~cm}^{-}$ 1 observed in the non-chelating hybrid $\mathrm{Cu} /$ polyNPPBH/DNA [24]. It is likely that because of the reduced dimensionality, small tunneling junctions between $\mathrm{Cu}$ particles dominate the observed resistance.

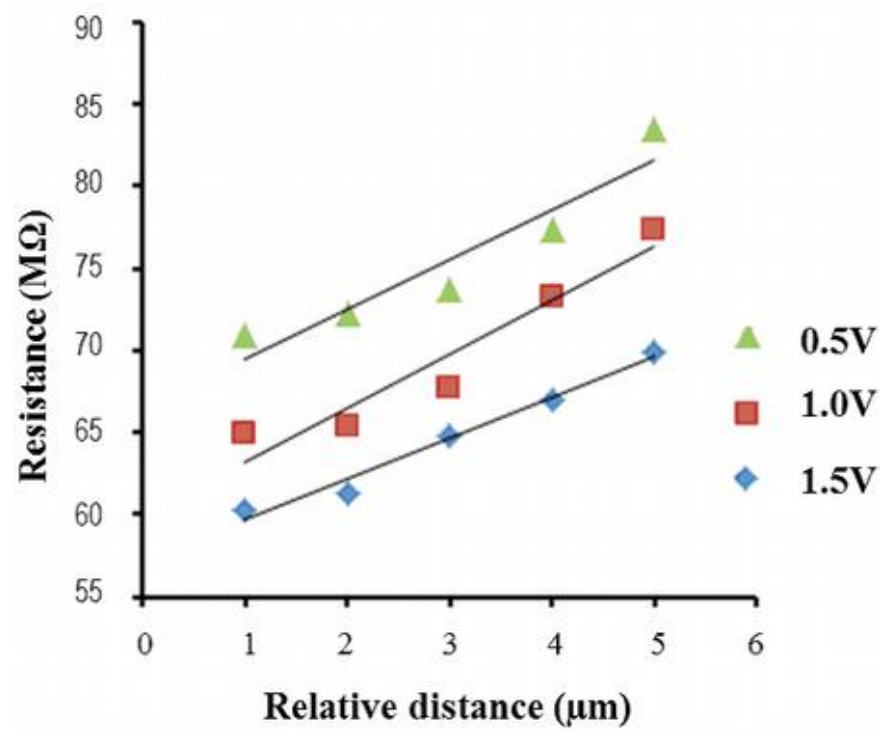

Figure 10: $\mathrm{Cu} /$ polyNP2PBH/DNA nanowire resistance at zero bias as a function of tip-contact relative distance for different applied forces (deflection set points $0.5-1.5 \mathrm{~V})$ in single-point cAFM I-V measurements.

\section{CONCLUSION}

PolyNP2PBH nanowires have been templated on $\lambda$ DNA in aqueous solution by oxidative polymerization using $\mathrm{FeCl}_{3}$ as the oxidant. NP2PBH is an Nderivatized pyrrole bearing 2,2'-bipyridyl groups suitable for metal binding. PolyNP2PBH/DNA nanowires were decorated with metals ( $\mathrm{Cu}$ and $\mathrm{Pd}$ ) by electroless deposition $\left[\mathrm{Cu}\left(\mathrm{NO}_{3}\right)_{2} /\right.$ ascorbate or $\left.\mathrm{PdCl}_{4}{ }^{2}-\mathrm{NaBH}_{4}\right]$ to produce metal shell/polymer core/DNA nanowires. FTIR spectroscopic studies 
confirmed that the polymer/nanowires are not a simple mixture and that the two types of polymer interact. This is indicated by shifts in bands associated with both the phosphodiester backbone and the nucleobases. Optical studies revealed an absorption peak at $550 \mathrm{~nm}$ corresponding to a surface plasmon resonance for $\mathrm{Cu}^{0}$ and a broad absorption band in the 300-700 nm region consistent with $\mathrm{Pd}^{0}$. The presence of elemental metal was confirmed by photoelectron spectroscopy.

AFM images show that the Cu/polyNP2PBH/DNA nanowires are regular and uniform if sufficiently long reaction times for electroless deposition are allowed (24 h). Less branching was observed than for the nonchelating $\mathrm{Cu} /$ polyNPPBH/DNA nanowires [24], which we attribute to improved nucleation of $\mathrm{Cu}^{0}$ on the polyNP2PBH. Pd/polyNP2PBH/DNA nanowires were less regular in shape than either $\mathrm{Cu} /$ polyNP2PBH/DNA or polyNP2PBH/DNA nanowires. SCM showed that these nanowires are all electrically conductive. However, Cu/polyNP2PBH /DNA showed uniform phase shifts, whereas SCM phase images of $\mathrm{Pd} /$ polyNP2PBH/DNA were less uniform. As expected from the SCM data, reproducible direct measurement of the conductivity was possible only for the $\mathrm{Cu} /$ polyNP2PBH/DNA nanowire. We observed a modest improvement in the conductivity of $\mathrm{Cu} /$ polyNP2PBH/DNA $(1.6 \pm 0.27 \mathrm{~S}$ $\mathrm{cm}^{-1}$ ) compared to the non-chelating NPPBH derivative $\left(0.42 \pm 0.019 \mathrm{~S} \mathrm{~cm}^{-1}\right)$ [24].

\section{ACKNOWLEDGEMENTS}

Sebha University, Higher Education, Libya for sponsorship (M.M.A.).

MMA and R.H. contributed equally to this work.

\section{REFERENCES}

[1] Z Chen, C. Liu, F. Cao, J. Ren, X. Qu, Chem. Soc. Rev. 2018, 47, 4017-4072.

[2] 2 A. Houlton and S. M. D. Watson, Annu. Rep. Prog. Chem., Sect.A: Phys. Inorg. Chem. 2011, 107, 21-42.

[3] N. C. Seeman, Nature 2003, 421, 427-431.

[4] N. C. Seeman, Nanotechnology 1991, 2, 149159.

[5] C. A. Mirkin, Inorg. Chem., 2000, 39, 22582272.

[6] A. J. Storm, J. van Noort, S. de Vries and C. Dekker, Appl. Phys. Lett. 2001, 79, 3881-3883.

[7] C. F. Monson and A. T. Woolley, Nano Lett., 2003, 3(3), 359-363.

[8] H. A. Becerril, R. M. Stoltenberg, C. F. Monson and A. T. Woolley, J. Mater. Chem. 2004, 14(4), 611-616.

[9] E. Braun, Y. Eichen, U. Sivan and G. BenYoseph, Nature 1998, 391, 775-778.

[10] J. Richter, R. Seidel, R. Kirsch, M. Mertig, W. Pompe, J. Plaschke and H. K. Schackert, Adv. Mater. 2000, 12, 507-510.

[11] L. Dong, T. Hollis, B. A. Connolly, N. G. Wright, B. R. Horrocks and A. Houlton, Adv. Mater. 2007, 19(13), 1748-1751.

[12] J. L. Coffer, S. R. Bigham, R. F. Pinizzotto and H. Yang, Nanotechnology 1992, 3, 69-76.

[13] L. Levina, W. Sukhovatkin, S. Musikhin, S. Cauchi, R. Nisman, D. P. Bazett-Jones and E. H. Sargent, Adv. Mater. 2005, 17, 1854-1857.

[14] Y. Ma, J. Zhang, G. Zhang and H. He, J. Am. Chem. Soc. 2004, 126, 7097-7101.

[15] P. Nickels, W. U. Dittmer, S. Beyer, J. P. Kotthaus and F. C. Simmel, Nanotechnology 2004, 15, 1524-1529.

[16] L. Dong, T. Hollis, S. Fishwick, B. A. Connolly, N. G. Wright, B. R. Horrocks and A. Houlton, Chem. Eur. J. 2007, 13, 822-828. 
[17] Md M. Hossen, L. Bendickson, P. E. Palo, Z. Yao, M. Nilsen-Hamilton and A. C. Hillier, Nanotechnology 2018, 29, 355603.

[18] B. Uprety, T. R. Westover, M. Stoddard, K. Brinkerhoff, J. Jensen, R. C. Davis, A. T. Woolley and J. N. Harb, Langmuir 2017, 33(3), 726-735

[19] B. R. Aryal, T. R. Westover, D. R. Ranasinghe, D. G. Calvopiña, B. Uprety, J. N. Harb, R. C. Davis and A. T. Woolley, Langmuir, 2018, 34(49), 15069-15077

[20] R. A. Matula, J.Phys. Chem. Ref. Data 1979, 8(4), 1147-1298.

[21] S. M. D. Watson, N. G. Wright, B. R. Horrocks and A. Houlton, Langmuir 2010, 26(3), 20682075.

[22] Y. Geng, A. C. Pearson, E. P. Gates, B. Uprety, R. C. Davis, J. N. Harb and A. T. Woolley, Langmuir 2013, 29(10), 3482-3490.

[23] J. Pate, F. Zamora, S. M. D. Watson, N. G. Wright, B. R. Horrocks and A. Houlton, J. Mater. Chem. C 2014, 2(43), 9265-9273.

[24] R. Hassanien, M. M. Almaky, A. Houlton and B. R. Horrocks, RSC Adv. 2016, 6(101), 99422-99432.

[25] C. Fang, Y. Fan, J. M. Kong, G. J. Zhang, L. Linn and S. Rafeah, Sens. Actuator B-Chem. 2007, 126(2), 684-690.

[26] F. Yang, S. C. Kung, M. Cheng, J. C. Hemminger and R. M. Penner, ACS Nano, 2010, 4, 5233-5244.

[27] M. N. Al-Hinai, R. Hassanien, N. G. Wright, A. B. Horsfall, A. Houlton and B. R. Horrocks, Faraday Discuss. 2013, 164,71-91.

[28] J. Richter, M. Mertig, W. Pompe, I. Mönch and H. K. Schackert, Appl. Phys. Lett. 2001, 78(4), 536-538.

[29] S. Kundu, K. Wang, D. Huitink and H. Liang, Langmuir 2009, 25(17), 10146-10152.
[30] K. Nguyen, S. Campidelli and A. Filoramo, Methods in Molecular Biology (Clifton, N.J.) 2011, 749, 49-59.

[31] M. Al-Hinai, R. Hassanien, S. M. D. Watson, N. G. Wright, A. Houlton and B. R. Horrocks, Nanotechnology 2016, 27(9), 095704.

[32] R. J. Waltman and J. Bargon, Can. J. Chem. 1986, 64(1), 76-95.

[33] Q. Wu, G. D. Storrier, K. R. Wu, J. P. Shapleigh and H. D. Abruña, Anal. Biochem. 1998, 263(1), 102-112.

[34] B. R. Saunders, R. J. Fleming and K. S. Murray, Chem. Mater. 1995, 7(6), 1082-1094.

[35] D. Bensimon, A. J. Simon, V. Croquette and A. Bensimon, Phys. Rev. Lett. 1995, 74(23), 47544757.

[36] R. J. Waltman, A. F. Diaz and J. Bargon, J. Phys. Chem. 1984, 88(19), 4343-4346.

[37] J. Heinze, Synth. Met., 1991, 43(1-2), 28052823.

[38] A. F. Diaz, J. Castillo, K. K. Kanazawa, J. A. Logan, M. Salmon and O. Fajardo, J. Electroanal. Chem. 1982, 133(2), 233-239.

[39] K. Takada, Z. Naal and H. D. Abruña, Langmuir 2003, 19(13), 5402- 5406.

[40] P. W. Hansen and P. W. Jensen, Spectrochim. Acta A 1994, 50(1), 169-183.

[41] J. L. Duan, T. W. Cornelius, J. Liu, S. Karim, H. J. Yao, O. Picht, M. Rauber, S. Müller and R. Neumann, J. Phys. Chem. C 2009, 113(31), 13583-13587.

[42] J. A. Creighton and D. G. Eadon, J. Chem. Soc. Faraday Trans. 1991, 87, 3881-3891.

[43] T.-Y. Chen, S.-F. Chen, H.-S. Sheu and C.-S. Yeh, J. Phys. Chem. B. 2002, 106, 9717-9722.

[44] F. M. Capece, V. D. Castro, C. Furlani, G. Mattogno, C. Fragale, M.

[45] Gargano and M. J. Rossi, Electron. Spectrosc. Relat. Phenom. 1982, 27, 119-128.

[46] J. C. Fuggle, E. Källne, L. M. Watson and D. J. Fabian, Phys. Rev. B 1977, 16(2), 750-761. 
[47] S. Pruneanu, S. A. F. Al-Said, L. Dong, T. A. Hollis, M. A. Galindo, N. G. Wright, A. Houlton and B. R. Horrocks, Adv. Funct. Mater. 2008, 18(16), 2444-2454.

[48] S. M. D. Watson, M. A. Galindo, B. R. Horrocks, and A. Houlton, J. Am. Chem. Soc. 2014, 136(18), 6649-6655.

[49] C. Staii, A. T. Johnson and N. J. Pinto, Nano Lett. 2004, 4(5), 859- 862.

[50] T. S. Jespersen and J. Nygård, Nano Lett. 2005, 5(9), 1838-1841.

[51] R. Hassanien, M. Al-Hinai, S. A. F. Al-Said, R. Little, L. Šiller, N. G. Wright, A. Houlton and B. R. Horrocks, ACS Nano 2010, 4(4), 21492159.First Author and Second Author. 2002. International Journal of Scientific Research in Science, Engineering and Technology. (Nov.2002)

\section{Cite this article as :}

Mahdi Almaky, Reda Hassanien, William Clegg, Ross Harrington, Andrew Houlton, Benjamin Horrocks, "Metal-Conductive Polymer Core-Shell Nanowires: Electroless Reduction of $\mathrm{Pd}$ and $\mathrm{Cu} \mathrm{On}$ Polypyrrole/DNA Templates Bearing 2-2'-Bipyridyl Groups", International Journal of Scientific Research in Science and Technology (IJSRST), Online ISSN : 2395-602X, Print ISSN : 2395-6011, Volume 7 Issue 2, pp. 406-423, March-April 2020. Available at doi : https://doi.org/10.32628/IJSRST207250 Journal URL : http://ijsrst.com/IJSRST207250 